\title{
Longterm Effects of Rituximab on B Cell Counts and Autoantibody Production in Rheumatoid Arthritis: Use of High-sensitivity Flow Cytometry for More Sensitive Assessment of B Cell Depletion
}

\author{
Andrea Váncsa, Zoltán Szabó, Szilvia Szamosi, Nóra Bodnár, Edit Végh, Lajos Gergely, \\ Gabriella Szúcs, Sándor Szántó, and Zoltán Szekanecz
}

ABSTRACT. Objective. To assess the efficacy and safety of longterm rituximab (RTX) therapy for rheumatoid arthritis (RA) and study correlations among B cell depletion, clinical response, and autoantibody production.

Methods. Seventy-seven patients with moderate or high RA activity received RTX and were re-treated every 6 months regardless of clinical response. All patients received at least 5 cycles. We assessed 28-joint Disease Activity Score (DAS28), IgM rheumatoid factor (RF), and anticitrullinated protein antibody (ACPA) levels at baseline, after 15 days, and then every 6 months for 24 months Absolute CD19+ B lymphocyte counts were determined in 50 patients using high-sensitivity flow cytometry (hsFACS) by reading 100,000 events.

Results. After 6, 12, 18, and 24 months, $51.6 \%, 51.9 \%, 73.3 \%$, and $83.8 \%$ of patients, respectively, showed good European League Against Rheumatism responses. Significant and sustained decreases in IgM RF and ACPA levels were observed as early as 6 months and 12 months, respectively. The baseline mean absolute B cell number was $0.234 \mathrm{~g} / \mathrm{l}$. B cell numbers diminished significantly after the very first infusion by Day $15(0.104 \mathrm{~g} / \mathrm{l} ; \mathrm{p}=0.007)$; they further decreased until 24 months $(0.0013 \mathrm{~g} / \mathrm{l} ; \mathrm{p}<0.001)$. One RTX infusion resulted in incomplete depletion in $76.7 \%$ of patients. Upon RTX treatment, changes in CD19+ B cell numbers positively correlated with changes in DAS28 $(r=0.963, p=0.008)$ and $\operatorname{IgM} R F(r=0.859, p=0.028)$, but not with changes in ACPA production $(\mathrm{r}=0.726, \mathrm{p}=0.102)$. The correlations between $\mathrm{B}$ cell numbers and DAS28 were observed in both ACPA-seropositive $(r=0.999, \mathrm{p}<0.0001)$ and ACPA-negative patient subpopulations $(r=0.962, p=0.009)$. The correlation between CD19+ cell numbers and IgM RF was observed only in the ACPA-positive population $(\mathrm{r}=0.944, \mathrm{p}=0.005)$ but not in seronegative patients $(\mathrm{r}=$ $0.398, \mathrm{p}=0.435)$. No safety issues arose.

Conclusion. In RA, clinical response to RTX is associated with the extent of B cell depletion and with autoantibody production. Changes in CD19+ B cell numbers correlate with those in disease activity and, in seropositive patients, also with IgM RF, but not with ACPA production. We found that hsFACS may be a useful method to more accurately assess incomplete B cell depletion. (First Release April 1 2013; J Rheumatol 2013;40:565-71; doi:10.3899/jrheum.111488)

Key Indexing Terms:

RHEUMATOID ARTHRITIS

B CELL DEPLETION

\author{
BIOLOGICAL THERAPY \\ B CELL NUMBER
}

\section{RITUXIMAB \\ FLOW CYTOMETRY}

The introduction of biologic disease-modifying agents into the management of rheumatoid arthritis (RA) has led to significant improvement in outcome measures, physical function, and quality of life. In addition to anticytokine and anti-T cell therapies, the monoclonal anti-CD20 antibody rituximab (RTX) has become the first biologic that targets B
From the Department of Rheumatology and the Third Department of Medicine, Division of Hematology, Institute of Medicine, University of Debrecen Medical and Health Sciences Center, Debrecen, Hungary.

Supported by an ETT 315-10 grant from the Medical Research Council of Hungary to Dr. Szekanecz.

A. Váncsa, MD, PhD; Z. Szabó, PhD; S. Szamosi, PhD; N. Bodnár, MD; E. Végh, MD, Department of Rheumatology, Division of Hematology, Institute of Medicine, University of Debrecen Medical and Health Sciences Center; L. Gergely, PhD, Third Department of Medicine, Division of Hematology, Institute of Medicine, University of Debrecen
Medical and Health Sciences Center; G. Szücs, PhD; S. Szántó, PhD; Z. Szekanecz, PhD, DSc, Department of Rheumatology, Division of Hematology, Institute of Medicine, University of Debrecen Medical and Health Sciences Center.

Address correspondence to Dr. A. Váncsa, University of Debrecen Medical and Health Sciences Center, Institute of Medicine, Department of Rheumatology, Nagyerdei str. 98, Debrecen 4032, Hungary.

E-mail: andrea.vancsa@gmail.com

Accepted for publication January 11, 2013. Personal non-commercial use only. The Journal of Rheumatology Copyright (C) 2013. All rights reserved. 
cells. There is a need for biologics that act on new targets because, based mostly on clinical studies, $25 \%-40 \%$ of patients with RA do not fulfill the American College of Rheumatology-20 response criteria upon treatment with tumor necrosis factor- $\alpha$ (TNF- $\alpha$ ) inhibitors ${ }^{1,2,3,4}$.

RTX causes a rapid and complete depletion of CD20+ B lymphocytes in the bone marrow and incomplete depletion in the peripheral blood. The effects of RTX are exerted by antibody-dependent and complement-mediated cytotoxicity, as well as apoptosis-inducing effects that last for a minimum of 16 weeks $^{2}$. Studies confirmed that RTX decreased rheumatoid factor (RF) and anticitrullinated protein antibodies (ACPA) in parallel with clinical response ${ }^{5,6}$. Several biomarkers are under investigation that may predict clinical responsiveness to RTX therapy. These possible predictive biomarkers include circulating interferon- $\gamma$, "A" proliferation-inducing ligand, B cell activating factor/B lymphocyte stimulator levels, Fc $\gamma$ receptor III genotype, and the presence of interleukin 6 gene C/G-174 polymorphism ${ }^{7,8,9,10,11,12}$. Some authors suggest that good clinical response to RTX may also be related to RF but possibly not with ACPA seropositivity $8,13,14$ and with decreases in RF and ACPA levels $6,8,12$.

There is no consensus regarding the association of clinical response to RTX with B cell numbers and with B cell recovery after complete depletion. In some studies, clinical nonresponse, as well as relapses during and after RTX treatment, have been associated with incomplete B cell depletion, higher baseline number of preplasma cells, and the persistence of long-lived plasma cells ${ }^{15,16,17,18}$. In contrast, Breedveld, et $a l^{19}$ could not find a correlation between clinical response and B cell numbers. In that study, $\mathrm{B}$ cell recovery did not correlate with clinical relapse. Because CD20+ B lymphocytes are absent from or hardly detectable in the blood by flow cytometry (FACS) upon RTX treatment, it has been difficult to determine a relationship between the extent of $\mathrm{B}$ cell depletion and the clinical response. Even if complete depletion of blood B cells is achieved, that is not the case in the synovial tissue, which may have great influence on clinical response ${ }^{1,2,5}$. Yet it has been suggested that primary nonresponsiveness may strongly depend on preplasma cell counts and the extent of peripheral blood B cell depletion ${ }^{8}$. As discussed, it is difficult to differentiate between complete and incomplete $\mathrm{B}$ cell depletion using conventional FACS analysis, where the minimal detectable number of B cells would be $0.05 \mathrm{~g} / \mathrm{l}$. Yet high-sensitivity FACS (hsFACS), used by hematologists to detect minimal residual disease in lymphomas, may also be applied to patients with $\mathrm{RA}^{18}$.

Because there have been very few studies using hsFACS to assess $\mathrm{B}$ cell depletion in $\mathrm{RA}^{18}$ and few groups have assessed the effects of RTX on RF and ACPA levels ${ }^{5,6}$, we analyzed the association of response to RTX with these biomarkers in Hungarian patients with RA.

\section{MATERIALS AND METHODS}

Patients and treatment protocol. We performed a prospective analysis of 77 patients with RA (65 women, 12 men) with a mean age of $52.8 \pm 12.8$ years (range 20-79 yrs) and a median disease duration of $12.5 \pm 11.1$ years (range 2-41 yrs) who had undergone RTX treatment in our department. Table 1 gives demographic data for these patients. None of the patients achieved seroconversion for ACPA or RF during the course of the study. All patients had either active [28-joint Disease Activity Score (DAS28) $\geq 5.1, \mathrm{n}=47$ ] or moderately active disease (DAS28 $>3.2, \mathrm{n}=30$ ) despite previous anti-TNF therapy. All patients received $1000 \mathrm{mg}$ RTX therapy 2 weeks apart, on Days 1 and 15. The same dose and protocol were applied to re-treatment cycles. According to the recommendations, $100 \mathrm{mg}$ intravenous methylprednisolone and antihistamine were administered prior to the infusions to prevent infusion reactions. Patients continued methotrexate therapy in stable doses of 15-25 mg/week. Regular re-treatment with RTX was performed every 6 months in a fixed manner regardless of the extent of clinical response or the observed peripheral CD19+ B cell counts. Only patients receiving at least 5 cycles (1 first treatment and 4 re-treatment cycles in 24 months) and having further followup for $\geq 48$ months were included in the study.

All subjects gave informed consent for the study. The study received Institutional Review Board ethical approval.

Clinical and serological assessments. History, baseline characteristics, and demographic data were recorded (Table 1) and physical examinaton was performed in each patient at baseline and every 6 months. Blood samples were also taken and erythrocyte sedimentation rate, C-reactive protein, IgM RF, and ACPA were assessed at baseline, before the second infusion of the first RTX cycle on Day 15, and then before each re-treatment cycle every 6 months. IgM RF was detected by Cobas Mira Plus (Roche Laboratories) quantitative nephelometry (Dialab). ACPA concentrations were detected using the second-generation ELISA method (ACPA; Inova). Cutoff values for IgM RF and ACPA were $<50$ and $<25 \mathrm{U} / \mathrm{ml}$, respectively. Clinical responsiveness was determined by the European League Against Rheumatism (EULAR) response criteria based on the improvement in 3-variable DAS28 scores.

B cell assessment by hsFACS. CD19+ B cell counts were also assessed in 50 patients at baseline, before the second infusion of the first RTX cycle (Day 15) and then before each cycle. B cell counts were determined by hsFACS analysis. Freshly drawn heparin-anticoagulated peripheral blood samples were used for flowmetry. Blood samples of $100 \mu 1$ were stained with the recommended amount of fluorochrome-conjugated monoclonal antibodies (CD5-FITC: Becton-Dickinson; CD19-PC5: Immunotech; CD20-PE: Dako) at room temperature in the dark for $20 \mathrm{~min}$. Red blood cells were lysed by hyposmotic solution and then samples were washed twice with phosphate buffered saline $\mathrm{pH}$ 7.4. Samples were then fixed in $1 \%$ paraformaldehyde solution and stored at $4^{\circ} \mathrm{C}$. The Cytomics FC500

Table 1. Baseline patient characteristics.

\begin{tabular}{lc} 
Characteristic \\
\hline No. patients & 77 \\
Female:male ratio & $62: 15$ \\
Age, yrs, mean \pm SD (range) & $52.8 \pm 12.8(20-79)$ \\
Disease duration, yrs, mean \pm SD (range) & $12.5 \pm 11.1(2-41)$ \\
IgM RF-positive patients, $\mathrm{n}(\%)$ & $40(52)$ \\
ACPA-positive patients, $\mathrm{n}(\%)$ & $58(75)$ \\
DAS28, baseline; mean \pm SD (range) & $5.36 \pm 0.34(3.8-7.7)$ \\
$\quad$ Swollen joint count & $7.2 \pm 4.9(0-16)$ \\
Tender joint count & $8.7 \pm 4.2(2-18)$ \\
Erythrocyte sedimentation rate, $\mathrm{mm} / \mathrm{h}$ & $39.2 \pm 12.5(10-66)$ \\
\hline
\end{tabular}

RF: rheumatoid factor; ACPA: anticitrullinated protein antibodies; DAS28: 28-joint Disease Activity Score. 
flow cytometer (Beckman-Coulter), using CXP software, performed the hsFACS analysis of samples. Lymphocytes were gated on the forward scatter versus side scatter histogram, and 100,000 lymphocytes were assessed to obtain high sensitivity data. Both CD19+ and CD20+ cells were analyzed to exclude the CD20 masking effect caused by RTX. Total B cell counts were calculated by multiplying total lymphocyte counts by the percentage of B cells within the lymphocyte population. An example is shown in Figure 1. We considered depletion complete if absolute B cell counts were $<0.0001 \mathrm{~g} / 1$.

Data analysis. Correlations between the IgM RF and ACPA levels, clinical improvement, and decreases in absolute CD19+ B cell counts were determined. We also assessed the timeline when reduction in cell numbers would be significant compared to baseline measures. Statistical analysis was performed with SPSS software version 15.0. Friedman, Wilcoxon, and paired $\mathrm{t}$ tests were used for statistical analysis. $\mathrm{P}$ values $<0.05$ were considered statistically significant.

\section{RESULTS}

Clinical responses. All patients received at least 4 cycles of re-treatment in a fixed manner every 6 months. The primary outcome measure was clinical efficacy as determined by EULAR response. Secondary outcome measures were changes in DAS28, IgM RF, and ACPA levels. RTX was effective in suppressing disease activity as indicated by statistically significant improvement in DAS28 scores observed after the first cycle (Table 2). Indeed, the mean baseline DAS28 (5.36) was significantly decreased to 4.07 after 6 months, and continued to decrease to 3.99 after 12 months, 3.58 after 18 months, and 3.43 after 24 months (Table 2, Figure 2). After 6, 12, 18, and 24 months of RTX therapy, $51.6 \%, 51.9 \%, 73.3 \%$, and $83.8 \%$ of patients showed good EULAR response, respectively (Figure 2). At these timepoints, $20.9 \%, 25.0 \%, 15.6 \%$, and $12.9 \%$ of patients had moderate EULAR response (Figure 2).

Clinical response did not correlate with age, sex, disease duration, or ACPA positivity (data not shown).

Decreases in IgM RF, ACPA levels, and B cell counts. IgM RF levels dropped significantly by 6 months after treatment (Table 2, Figure 3). The mean baseline IgM RF concen- tration was $198.9 \mathrm{U} / \mathrm{ml}$, which decreased significantly to $93.5,44.7,28.6$, and $21.1 \mathrm{U} / \mathrm{ml}$ by $6,12,18$, and 24 months, respectively (Table 2, Figure 3 ).

Baseline mean ACPA level was $473.5 \mathrm{U} / \mathrm{ml}$, which decreased significantly to $421.7,244.9$, and $168.3 \mathrm{U} / \mathrm{ml}$ by 12, 18, and 24 months, respectively (Table 2, Figure 3).

Peripheral CD19+ B cell counts were determined by hsFACS analysis (Figure 1). The median baseline CD19+ B cell count was 0.234 (range $0-1.15$ ) g/l. RTX treatment resulted in rapid and significant B cell depletion as early as the 15 th day after initiation of RTX therapy $(0.104 \mathrm{~g} / \mathrm{l} ; \mathrm{p}=$ $0.007)$, and the decrease in B cell counts was sustained (Table 2, Figure 3). After 6, 12, 18, and 24 months, the median absolute CD19+ B cell counts were 0.026 (range $0-0.27), 0.016(0-0.24), 0.006(0-0.034)$, and 0.0013 $(0-0.003) \mathrm{g} / 1$, respectively ( $\mathrm{p}<0.001$ vs baseline; Figure 4). While CD19+ B cells could be detected in the blood of all patients prior to RTX therapy, at 2 weeks and at $6,12,18$, and 24 months after the very first infusion, 76.7\%, 75.7\%, $70.8 \%, 56.5 \%$, and $50.0 \%$ of patients, respectively, had detectable CD19+ B cells in their peripheral blood.

Correlations between B cell numbers, IgM RF, ACPA, and clinical activity. Absolute $\mathrm{B}$ cell numbers determined by hsFACS were correlated with disease activity, as well as with serum IgM RF and ACPA serum levels. Upon RTX therapy, changes in B cell numbers showed significant positive correlations with those in DAS28 ( $\mathrm{r}=0.963, \mathrm{p}=$ $0.008)$ and in $\operatorname{IgM} \operatorname{RF}(r=0.859, p=0.028)$, but not with changes in ACPA production $(r=0.726, p=0.102)$.

The correlations between $\mathrm{CD} 19+\mathrm{B}$ cell number and DAS28 changes were observed in both ACPA-seropositive $(\mathrm{r}=0.999, \mathrm{p}<0.0001)$ and ACPA-negative patient subpopulations $(\mathrm{r}=0.962, \mathrm{p}=0.009)$. The correlation between CD19+ cell number and IgM RF changes was observed only in the ACPA-positive population $(r=0.944, p=0.005)$ but not in seronegative patients $(r=0.398, p=0.435)$. In addition, in ACPA-positive patients, DAS28 also correlated
[Ungated] SS Lin/FS Lin - ADC

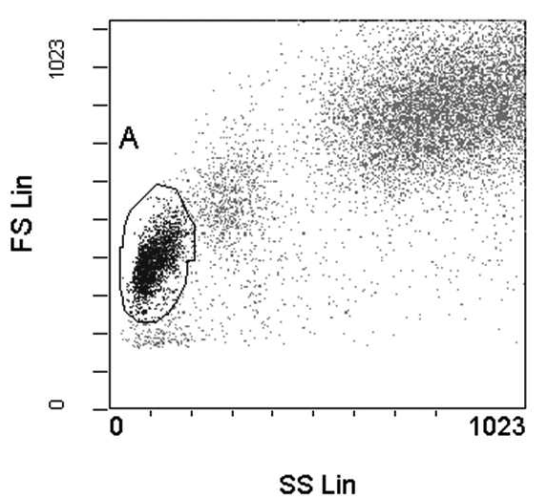

[A] FL1 Log/FL2 Log - ADC

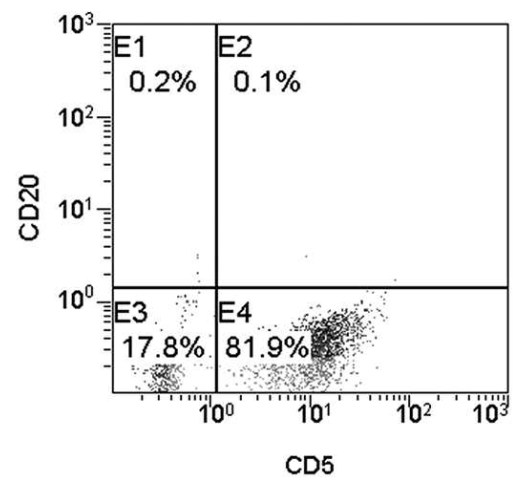

[Ungated] SS Lin/FL4 Log - ADC

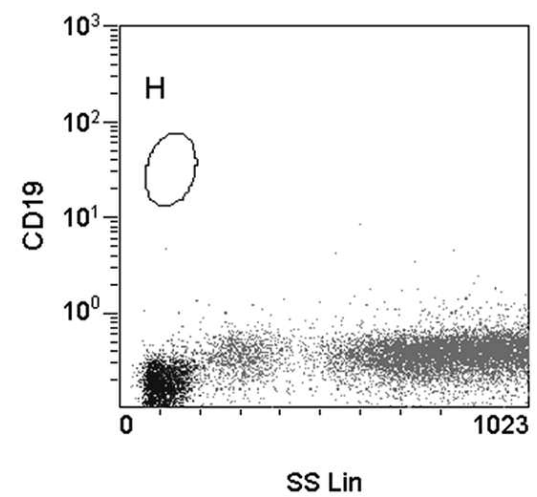

Figure 1. An example of high-sensitivity flow cytometry analysis. Lymphocytes were gated on the forward scatter (FS) versus side scatter (SS) histogram, and 100,000 cells were analyzed to obtain high-sensitivity data. B lymphocytes were detected by CD20 and CD19 immunophenotyping (not shown). Backgating was used to rule out abnormally shaped B cells.

Personal non-commercial use only. The Journal of Rheumatology Copyright (C) 2013. All rights reserved. 
Table 2. Changes in DAS28, IgM RF, ACPA concentrations, and peripheral CD19+ B cell numbers during subsequent cycles of ritximab. Values are mean \pm SD. Statistically significant differences are indicated in bold type.

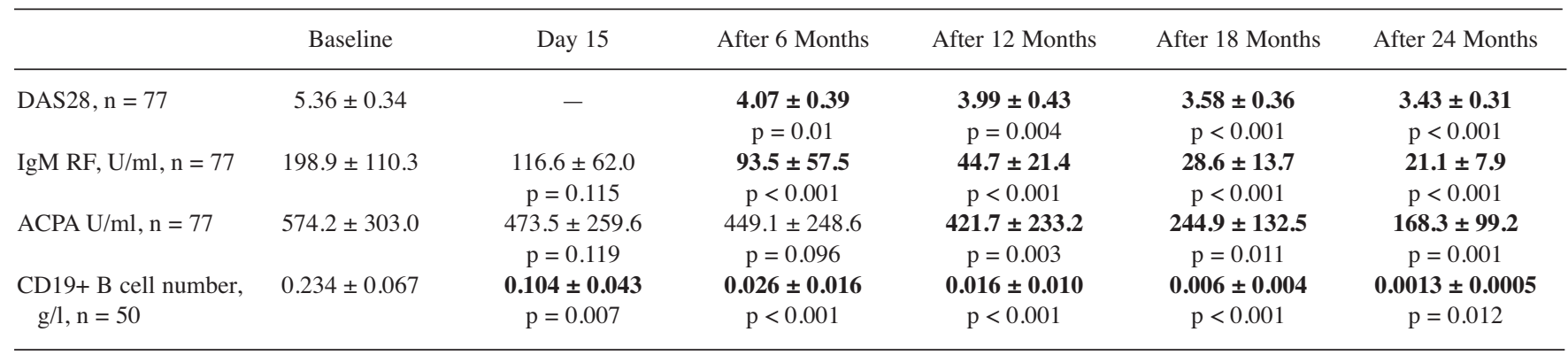

DAS28: 28-joint Disease Activity Score; RF: rheumatoid factor; ACPA: anticitrullinated protein antibodies.

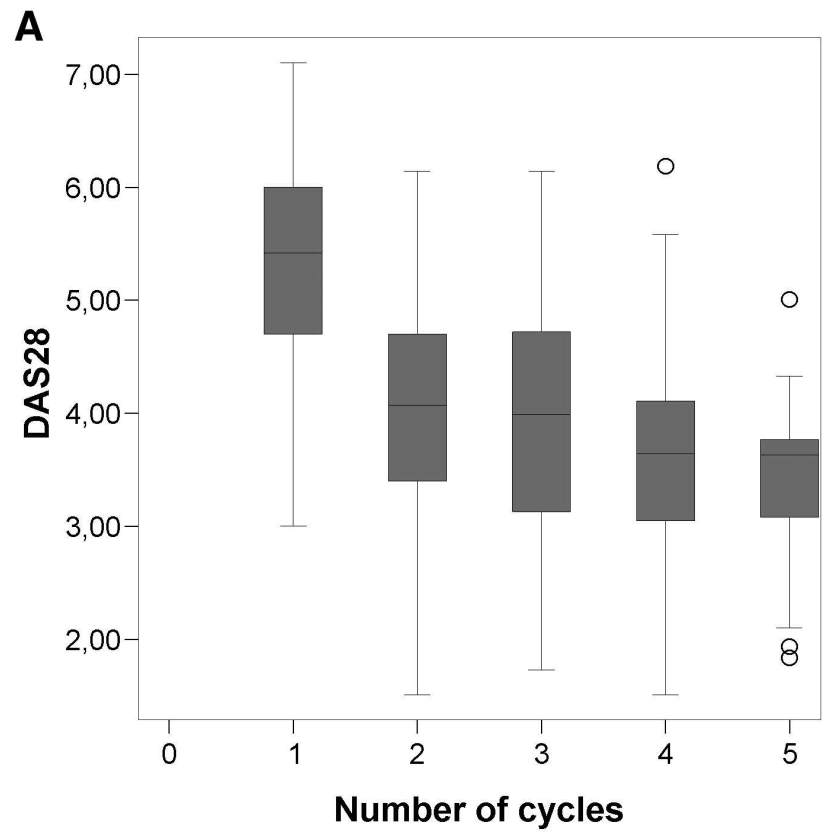

B

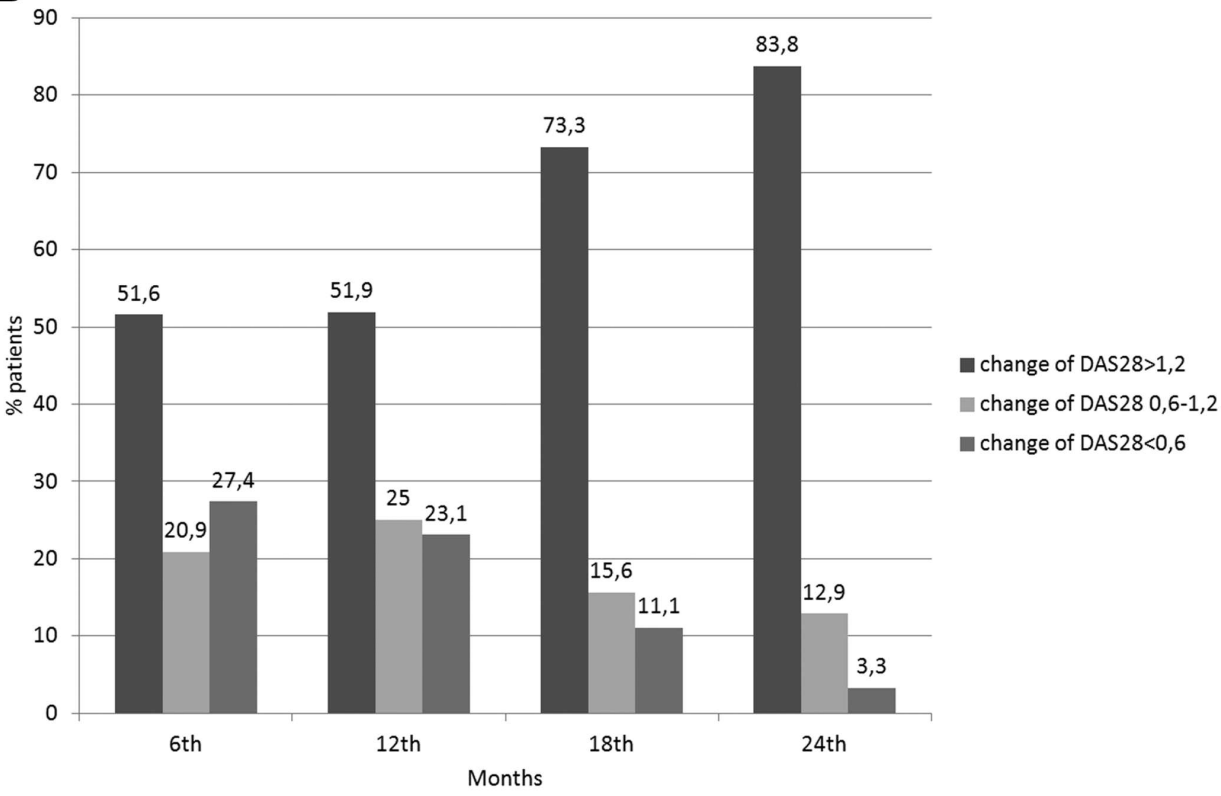

Figure 2. Disease activity indicated by the 28-joint Disease Activity Score (DAS28; A) and EULAR responses (B) in patients with RA during consecutive cycles of rituximab therapy. 


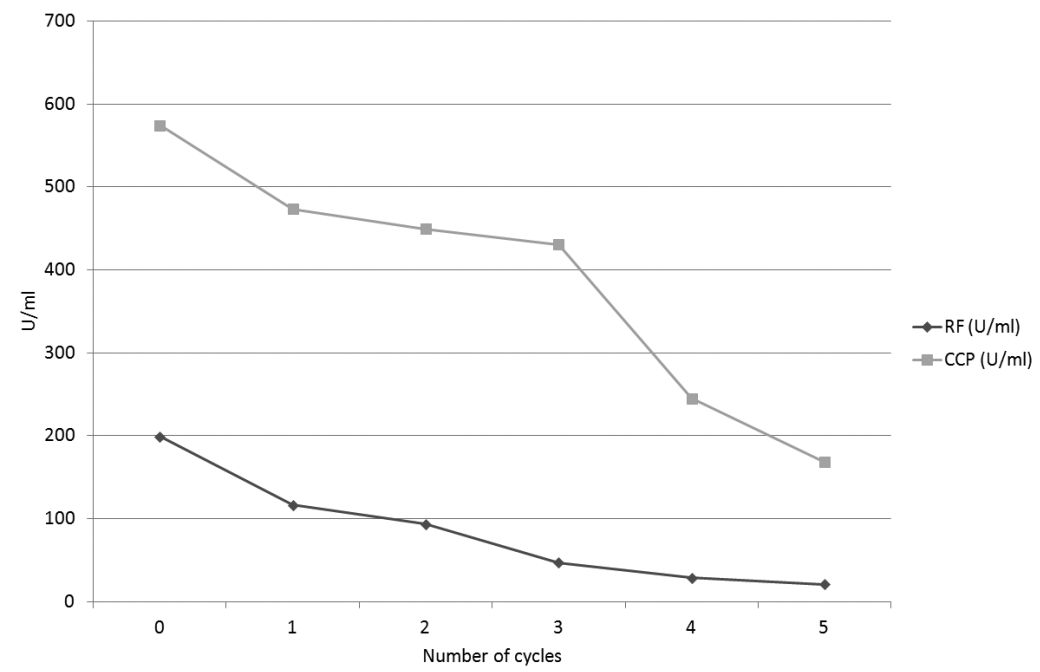

Figure 3. Effects of subsequent rituximab cycles on mean serum IgM rheumatoid factor (RF) and anticitrullinated protein antibody (CCP) concentrations.

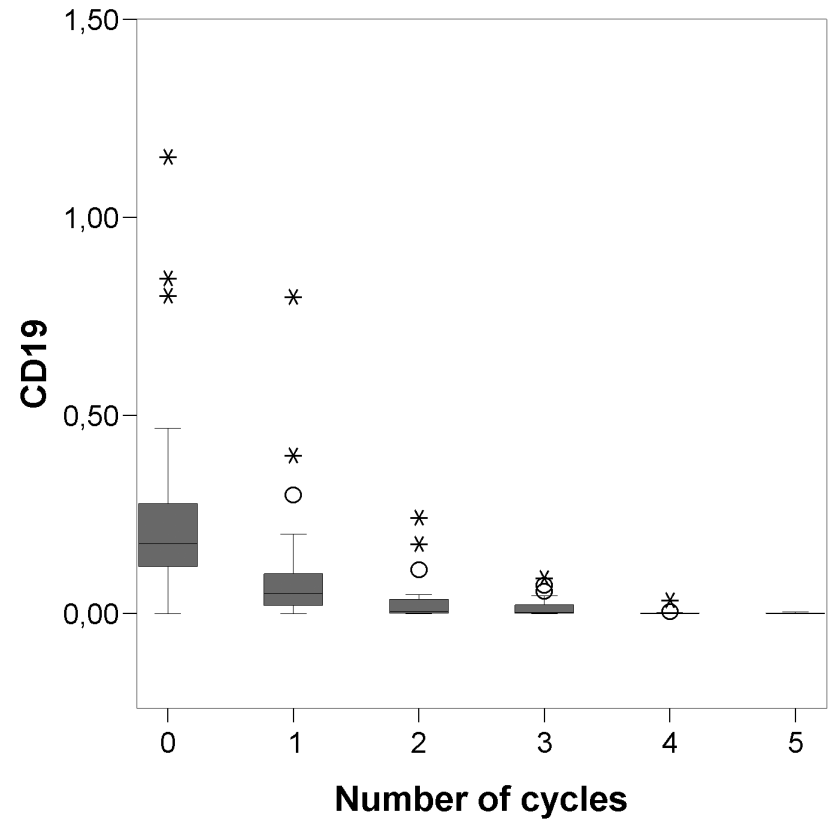

Figure 4. Effects of subsequent rituximab cycles on peripheral blood absolute CD19+ B cell numbers (median values $\pm \mathrm{SD}$ ).

positively with $\operatorname{IgM} \mathrm{RF}(\mathrm{r}=0.910, \mathrm{p}=0.032$; data not shown).

RTX safety. No serious adverse events and no serious infections were observed during 24 months of therapy. RTX therapy had to be terminated after 4 cycles of re-treatment (> 24 months) in 8 patients $(10.4 \%)$ because of minor side effects such as herpetic keratitis (1 case), herpes zoster (1 case), infusion reactions (2 cases), cervical intraepithelial neoplasia ( 1 case), and secondary inefficacy ( 3 cases). Mild common cold and flu-like symptoms occurred in 4 patients, but treatment termination was not required. In general, most patients tolerated RTX well.

\section{DISCUSSION}

Our results indicate good clinical response to RTX in association with a sustained decrease of circulating B cell numbers as determined by hsFACS, as well as IgM RF and ACPA levels. Significant improvement in DAS28 was already observed after the first pair of infusions, before the 6-month re-treatment. Accordingly, IgM RF levels decreased significantly in 6 months, while ACPA levels decreased in 12 months. The very first RTX infusion caused B cell depletion; peripheral blood CD19+ B cell counts dropped by Day 15 . The possible effect of the $100 \mathrm{mg}$ methylprednisolone on B cell depletion could be excluded. There has been only 1 study, from the 1970s, showing lymphopenia after pulse corticosteroid treatment; a complete recovery occurred within 24 hours $^{20}$.

Incomplete depletion of B cells from the peripheral blood may be strongly related to early inadequate clinical response ${ }^{15,16,17,18}$. At 100,000 cells/ $\mu 1$, hsFACS can detect complete B cell depletion (B cell count $<0.0001 \mathrm{~g} / \mathrm{l}$ ). This technique has been widely used in oncohematology to detect minimal residual disease in lymphomas and leukemias ${ }^{21,22}$. Its possible implications in rheumatology practice have not yet been established. One limitation may be the relatively higher cost. Dass, et al ${ }^{18}$ used hsFACS in patients with RA by detecting 500,000 events and suggested that incomplete depletion of B cells may be a key factor associated with initial, primary nonresponse to RTX. The updated consensus statement on RTX therapy states that in patients with RA, nonresponse to RTX is associated with incomplete B cell depletion and higher preplasma cell counts ${ }^{4}$. In such patients, second and further re-treatment cycles of RTX

$$
\text { Personal non-commercial use only. The Journal of Rheumatology Copyright @ } \subset \text { 2013. All rights reserved. }
$$


must be applied before B cell counts will return to normal ${ }^{4}$. It has been suggested that in numerous cases, a clinical relapse will follow the return of a normal B cell count ${ }^{5,18,23}$. Therefore it is recommended that the next cycle of RTX be applied regularly, according to a fixed re-treatment protocol $^{18,24}$. Moreover, after an initial moderate response to RTX, increased efficacy is seen in many patients during further re-treatment cycles.

In our cohort, changes in CD19+ B cell numbers correlated with those in clinical activity determined by DAS28 as well as with IgM RF, but not with ACPA production. Correlation between B cell numbers and DAS28 was observed in both ACPA-positive and negative patients, while correlation between B cell numbers and IgM RF was seen only in ACPA-seropositive patients. In addition, clinical response to RTX did not correlate with age, sex, disease duration, and ACPA status. As mentioned, other investigators did not find correlation between response and $\mathrm{ACPA}^{1,16,18}$.

We applied a fixed treatment protocol by administering $1000 \mathrm{mg}$ RTX in 2 doses of $500 \mathrm{mg} 2$ weeks apart every 6 months irrespective of initial response or nonresponse. As changes in the number of B cells correlated with changes in clinical activity and IgM RF production, the small resistant proportion of $\mathrm{B}$ cells may have important clinical relevance. Although minimal residual disease has not yet been defined in RA and other inflammatory diseases, we, like hematologists, tried to use hsFACS to determine incomplete B cell depletion.

The limitations of our study include the open-label design and the absence of a control group. In addition, some important dilemmas were raised that our study could not answer. The fixed treatment protocol may result in overtreatment of patients. However, because no serious adverse events were observed, this may not be an issue. Changes in B cell numbers strongly correlated with those in clinical activity and IgM RF production; however, the predictive value of baseline $B$ cell numbers and RF for clinical response is not fully clear and needs further confirmation.

RTX treatment results in peripheral blood CD19+ B cell depletion associated with attenuated production of IgM RF and ACPA. To assess even very low B cell counts, and thus more sensitively determine incomplete B cell depletion (a predictor of clinical response), hsFACS may be used. In clinical practice, hsFACS may be better than regular FACS analysis because hsFACS may still differentiate very low B cell counts from zero.

\section{REFERENCES}

1. Smolen JS, Keystone EC, Emery P, Breedveld FC, Betteridge N, Burmester GR, et al. Consensus statement on the use of rituximab in patients with rheumatoid arthritis. Ann Rheum Dis 2007; 66:143-50.
2. Cohen SB. Targeting the B cell in rheumatoid arthritis. Best Pract Res Clin Rheumatol 2010;24:553-63.

3. Keystone E, Emery P, Peterfy CG, Tak PP, Cohen S, Genovese MC, et al. Rituximab inhibits structural joint damage in patients with rheumatoid arthritis with an inadequate response to tumour necrosis factor inhibitor therapies. Ann Rheum Dis 2009;68:216-21.

4. Buch MH, Smolen JS, Betteridge N, Breedveld FC, Burmester G, Dorner T, et al. Updated consensus statement on the use of rituximab in patients with rheumatoid arthritis. Ann Rheum Dis 2011;70:909-20.

5. Thurlings RM, Vos K, Wijbrandts CA, Zwinderman AH, Gerlag DM, Tak PP. Synovial tissue response to rituximab: Mechanism of action and identification of biomarkers of response. Ann Rheum Dis 2008;67:917-25.

6. Cambridge G, Leandro MJ, Edwards JC, Ehrenstein MR, Salden M, Bodman-Smith M, et al. Serologic changes following B lymphocyte depletion therapy for rheumatoid arthritis. Arthritis Rheum 2003;48:2146-54.

7. Cambridge G, Stohl W, Leandro MJ, Migone TS, Hilbert DM, Edwards JC. Circulating levels of B lymphocyte stimulator in patients with rheumatoid arthritis following rituximab treatment: Relationships with B cell depletion, circulating antibodies, and clinical relapse. Arthritis Rheum 2006;54:723-32.

8. Benucci M, Manfredi M, Puttini PS, Atzeni F. Predictive factors of response to rituximab therapy in rheumatoid arthritis: What do we know today? Autoimmun Rev 2010;9:801-3.

9. Quartuccio L, Fabris M, Salvin S, Atzeni F, Saracco M, Benucci M, et al. Rheumatoid factor positivity rather than anti-CCP positivity, a lower disability and a lower number of anti-TNF agents failed are associated with response to rituximab in rheumatoid arthritis. Rheumatology 2009;48:1557-9.

10. Szodoray P, Szabó Z, Kapitány A, Gyetvai A, Lakos G, Szántó S, et al. Anti-citrullinated protein/peptide autoantibodies in association with genetic and environmental factors as indicators of disease outcome in rheumatoid arthritis. Autoimmun Rev 2010;9:140-3.

11. Anolik JH, Campbell D, Felgar RE, Young F, Sanz I, Rosenblatt J, et al. The relationship of Fc gamma RIIIa genotype to degree of B cell depletion by rituximab in the treatment of systemic lupus erythematosus. Arthritis Rheum 2003;48:455-9.

12. Dorner T, Kinnman N, Tak PP. Targeting B cells in immune-mediated inflammatory disease: A comprehensive review of mechanisms of action and identification of biomarkers. Pharmacol Ther 2010;125:464-75.

13. Sellam J, Hendel-Chavez H, Rouanet S, Abbed K, Combe B, Le Loët $\mathrm{X}$, et al. B cell activation biomarkers as predictive factors for the response to rituximab in rheumatoid arthritis: A six-month, national, multicenter, open-label study. Arthritis Rheum 2011;63:933-8.

14. Belmonte Serrano MA, Pincus T. Comment on: Rheumatoid factor positivity rather than anti-CCP positivity, a lower disability and a lower number of anti-TNF agents failed are associated with response to rituximab in rheumatoid arthritis. Rheumatology 2010;49:1795-6.

15. Levesque MC, St. Clair EW. B cell-directed therapies for autoimmune disease and correlates of disease response and relapse. J Allergy Clin Immunol 2008;121:13-21; quiz 22-13.

16. Vital EM, Dass S, Rawstron AC, Buch MH, Goëb V, Henshaw K, et al. Management of nonresponse to rituximab in rheumatoid arthritis: Predictors and outcome of re-treatment. Arthritis Rheum 2010;62:1273-9.

17. Vital EM, Dass S, Buch MH, Rawstron AC, Ponchel F, McGonagle $\mathrm{D}$, et al. Re-treatment of rheumatoid arthritis patients who were initial nonresponders to rituximab: comment on the article by Thurlings et al. Arthritis Rheum 2009;60:1867.

18. Dass S, Rawstron AC, Vital EM, Henshaw K, McGonagle D, 
Emery P. Highly sensitive B cell analysis predicts response to rituximab therapy in rheumatoid arthritis. Arthritis Rheum 2008;58:2993-9.

19. Breedveld F, Agarwal S, Yin M, Ren S, Li NF, Shaw TM, et al. Rituximab pharmacokinetics in patients with rheumatoid arthritis: B-cell levels do not correlate with clinical response. J Clin Pharmacol 2007;47:1119-28.

20. Fan PT, Yu DT, Clements PJ, Fowlston S, Eisman J, Bluestone R. Effect of corticosteroids on the human immune response: Comparison of one and three daily $1 \mathrm{gm}$ intravenous pulses of methylprednisolone. J Lab Clin Med 1978;91:625-34.

21. Kaleem Z, White G, Vollmer RT. Critical analysis and diagnostic usefulness of limited immunophenotyping of B-cell non-Hodgkin lymphomas by flow cytometry. Am J Clin Pathol 2001;115:136-42.
22. Shao H, Yuan CM, Xi L, Raffeld M, Morris JC, Janik JE, et al. Minimal residual disease detection by flow cytometry in adult T-cell leukemia/lymphoma. Am J Clin Pathol 2010;133:592-601.

23. Finckh A, Ciurea A, Brulhart L, Möller B, Walker UA, Courvoisier $\mathrm{D}$, et al. Which subgroup of patients with rheumatoid arthritis benefits from switching to rituximab versus alternative anti-tumour necrosis factor (TNF) agents after previous failure of an anti-TNF agent? Ann Rheum Dis 2010;69:387-93.

24. Teng YK, Tekstra J, Breedveld FC, Lafeber F, Bijlsma JW, van Laar JM. Rituximab fixed retreatment versus on-demand retreatment in refractory rheumatoid arthritis: Comparison of two B cell depleting treatment strategies. Ann Rheum Dis 2009;68:1075-7. 